was not stabilized until the 1990s. There was also a need for secrecy, because the export of Cinchona seeds or bark was illegal, and the Spanish colonies (and the republics that followed) had a monopoly on the raw material for the drug. The story of the theft of Cinchona has many parallels to the situation today. To whom do cures 'belong' - the people in the country where the plant grows, or those who discovered the use of the plant? And should we develop the drugs for profit or for philanthropy?

The story that Honigsbaum does not tell is that of the mosquito itself. Only some species of Anopheles transmit malaria, and their taxonomy is as complicated as that of Cinchona. Controlling the disease by destroying the mosquitoes that transmit it depends on first identifying them, a taxonomic tale not told in this book but perhaps the subject for another. Another problem was that distinguished medical men dismissed as fantastic the idea that mosquitoes transmit a filarial parasite that causes malaria - only dogged perseverance showed how wrong they were.

The development of synthetic drugs such as chloroquine and quinacrine made dependence on Cinchona bark a thing of the past, and an understanding of how the disease worked made control seem possible. But here this meant confronting the reality of nature. Malaria parasites evolve drug resistance, mosquitoes evolve pesticide resistance, and a vaccine seems as far away as ever, despite decades of research. The depressing observation by one of Honigsbaum's sources that "pharmaceutical companies are simply not interested in developing drugs for people who cannot afford shoes" shows that the tension between profit and philanthropy is still with us, just as it was in the hunt for Cinchona in the nineteenth century. But global warming and the concomitant spread of malaria to Europe and the United States may change all that. Malaria may become a disease of people who have shoes, and the impetus for drug and vaccine development may acquire new urgency.

One of the great riddles of malaria is how Cinchona's properties came to be discovered at all. Malaria did not exist in the New World until the Spanish and Portuguese arrived in the sixteenth century. Malaria is an Old World disease that was initially cured using a New World plant. Honigsbaum doesn't answer this conundrum, but he has written a fascinating book full of thought-provoking ideas. The seemingly arcane and out-of-date story of the hunt for a malaria cure brings home the timely message that knowledge of the world around us, from taxonomy, ecology and medicine, remains critical to our capacity for survival.

Sandra Knapp is in the Department of Botany,

The Natural History Museum, Cromwell Road, London SW7 5BD, UK.

\title{
A modern kind of magic
}

\section{Knowledge is Power: How Magic, the Government and an Apocalyptic Vision Inspired Francis Bacon to Create Modern Science \\ by John Henry \\ Icon Books/Totem Books: 2002. 176 pp. $£ 9.99 / \$ 15$}

\section{Alan Stewart}

The sensational claims of the book's subtitle are highlighted by a cover illustration of Gerrit Dou's mid-seventeenth-century depiction of an astronomer working by candlelight, hinting at some sort of supernatural skulduggery. It must be said that Dou's astronomer doesn't look anything like Francis Bacon, Baron Verulam, and there are bound to be Bacon scholars who would baulk at the idea of magic and apocalyptic visions having much to do with baconian natural philosophy. But John Henry's short study makes an interesting case for looking at the supposed father of modern science in a slightly different light.

Some recent criticism of Bacon has taken issue with his continued pre-eminence in so many fields, and Henry readily admits that the man "made no new discoveries, developed no technical innovations, uncovered no previously hidden laws of nature". But he is convinced of Bacon's importance as "a philosopher of science - perhaps the first one who really mattered". Before Bacon, he argues, "there was no such thing as science in our modern sense of the word". He points to three key factors comprising Bacon's importance: an insistence on experimental method rather than armchair speculation; the notion that a new knowledge of nature should be turned to the practical benefit of mankind; and the championing of inductive over deductive logic. "In a very real sense," he concludes, "Bacon invented modern science."

This is all quite traditional. Where Henry makes the case more pertinently is in his reading of Bacon's motivations: one practical and one spiritual. Following recent biographical emphases, Henry stresses Bacon's status as a career civil servant, saying he "always believed that the fully comprehensive and practically useful science he envisaged could only properly be pursued under the aegis of the state". This vision, most fully explained in the description of Solomon's House in Bacon's fable New Atlantis, remained unrealized in his own lifetime. But Bacon was prophetic, Henry argues, in understanding the need for state subsidy of scientific experiment.

Perhaps the most compelling section of the book deals with Bacon's "magic", by which

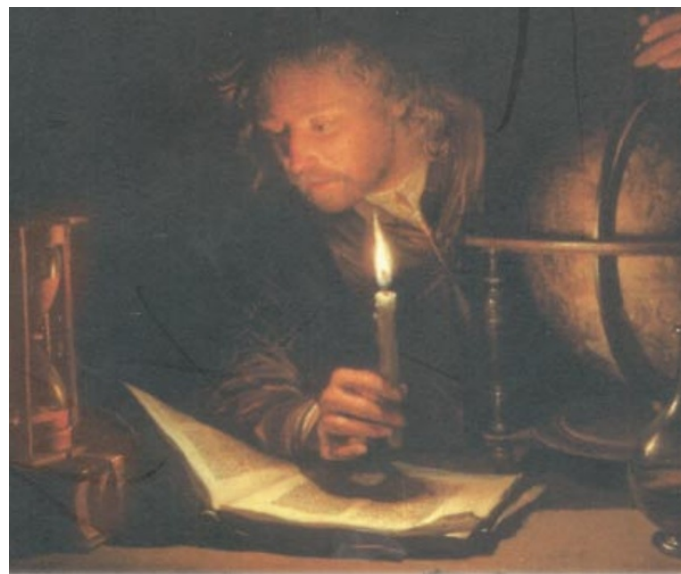

Dark forces? Gerrit Dou's painting Astronomer by Candlelight evokes a world of mystery.

Henry means religion. Here he makes a more convincing case than many for the profoundly religious underpinning of Bacon's philosophical project. The title page of the 1620 Novum Organum famously pictures the Straits of Gibraltar, the very edge of the Old World, and the motto "Multi pertransibunt et augebitur scientia" " Many will go to and fro, and knowledge will be increased"). As Henry notes, the line is taken from the Book of Daniel (chapter 12, verse 4), and Daniel is to the Old Testament what Revelations is to the New - here, then, is the apocalyptic vision.

Bacon firmly believed that he was living in the era in which the scriptures predicted that knowledge would increase beyond all recognition. Had not the past decades seen crucial advances in learning, warfare and navigation, in the form (respectively) of the printing press, gunpowder and the magnetic compass, he asked? Part of his Instauratio Magna was entitled Parasceve, the Greek word for 'preparation', but particularly the day of preparation for the Sabbath, the ultimate Sabbath of the Day of Judgement. "What else can the prophet mean... in speaking about the last times?" Bacon asked rhetorically in his Refutation of Philosophies in 1608. "Does he not imply that the passing to and fro or perambulation of the round earth and the increase or multiplication of science were destined to the same age and century?"

Henry expounds his case with the contagious, even bullish, enthusiasm of the committed teacher. The book is carefully pitched at an interested but not necessarily informed readership, and has a useful glossary of the more opaque technical terms and a brief practical guide for further reading. But although Knowledge is Power will find its primary audience as an introduction to Bacon, it still has something to offer the seasoned Bacon scholar.

Alan Stewart is in the School of English and

Humanities, Birkbeck, University of London, London WC1E 7HX, UK. 